\title{
Potential Use of King Coconut Husk as a Nutrient Source for Organic Coconut Cultivation
}

\author{
Herath, H.M.I.K. ${ }^{1{ }^{*}}$ and Wijebandara, D.M.D.I. ${ }^{2}$
}

\begin{abstract}
King coconut husk $(\mathrm{KCH})$ is a waste material from nut water processing industry which has no identified economic value, rather causing environmental problems. The $\mathrm{KCH}$ was used to develop a nutrient supplement material (NSM) by controlled combustion inside a kiln. Among the three categories of moist, semi-dry and dry coconut husk used for combustion, semi-dry $\mathrm{KCH}$ was found to be the best for processing in terms of time taken for the processing and ease of handling. The product was analyzed for nutrient availability and found that it contained considerable amounts of macro and micro nutrients. The developed NSM was then tested under field condition to investigate the potential for it to be used as a source of nutrient in coconut cultivation. The treatments were: T1- Recommended straight fertilizer (N, P, K) for coconut, T2- NSM was added as a source of $K$ while other nutrients were same as in $\mathrm{T} 1$, and $\mathrm{T} 3$ - $\mathrm{K}$ source supplied from sulfate of potash while other fertilizers were similar to $T 1$. Three months after treatment application, representative soil samples were extracted and tested for soil $\mathrm{pH}$, electrical conductivity and soil exchangeable potassium levels. According to the results, the product contained considerable amounts of
\end{abstract}

${ }^{1}$ Department of Plantation Management, Faculty of Agriculture and Plantation Management, Wayamba University of Sri Lanka, Makandura, Gonawila (NWP), 60170, Sri Lanka

${ }^{2}$ Soils and Plant Nutrition Division, Coconut Research Institute, Lunuwila, 61150, Sri Lanka

*indikaherath@wyb.ac.lk macro nutrients including $\mathrm{N}(2.1-2.4 \%)$ and $\mathrm{K}(8.8-13.1 \%)$, and micro nutrients including $\mathrm{Zn}(1350$ - $1522 \mathrm{ppm})$ and $\mathrm{Cu}(61.2$ - $62.5 \mathrm{ppm})$. The $K$ content of NSM was around three times higher than the $K$ content of other locally available organic manure. This indicates the potential of the product as a source of nutrient. Even though the $\mathrm{pH}$ of developed NSM product was higher (10.6), after application this product into soil, there was no significant difference among treatments. The NSM incorporated treatment showed significantly higher soil $K$ content compared to other treatments which indicates its potential to be used as a source of $K$ with organic manure for young coconut.

Keywords: King coconut husk, Organic nutrient sources, Potassium availability, Soil nutrient availability

\section{INTRODUCTION}

Demand for organic coconut products has rapidly increased over the last decade due to attractive prices paid for the organic products and due to the understanding of the need for safeguarding the environment. King coconut water dominates among highly demanded export products from coconut industry. King coconut water, the "Wonder Drink" is renowned for its multiple benefits. Sri Lanka is the main exporter of king coconut for different destinations around the globe including North America, Europe, Korea,

\footnotetext{
(CC) This article is published under the Creative Commons Attribution License (CC 4.0), which permitsunrestricted use, distribution, and reproduction in any medium, provided the original work is properly cited.
} 
Herath, H.M.I.K. and Wijebandara, D.M.D.I.

Japan and UK. In this industry, after king coconut water is extracted, the husk with immature coconut shell is discarded. During the peak production times, heaps of these King Coconut Husks $(\mathrm{KCH})$ are dumped. Furthermore, the husks of locally consumed king coconut are discarded with no proper use at the selling points. As king coconut is harvested immaturely, the husk has no economic value as it cannot be used for coir pith and fiber. Moreover, it has also been identified that these husks with immature shells become breeding grounds for mosquitoes during the rainy period.

Mainly, king coconut is exported as an organically certified product following the process of international certification for organic products. In organic cultivation, use of chemically formulated fertilizers are not permitted. Therefore, growers use organic sources of nutrients mainly through compost and manure. However, these sources are deficient in potassium (Tennakoon and Bandara, 2003). Furthermore, most of the coconut growing soils in Sri Lanka are very low in their potassium levels (Herath et al., 2007; Herath et al., 2008). Therefore, it is recommended to use a potassium source together with organic manure. Research conducted on potential use of potassium containing minerals/rocks such as mica and feldspar to meet potassium need of crops has shown that releasing of potassium from these materials is very slow (Cooray et al., 1992; Herath, 2014), while the demand for potassium by coconut is very high.
Unavailability of organic potassium source therefore remains as a constraint for expanding organic coconut production. Even though some potassium sources like sulfate of potash (SOP) are allowed to use in organic plantations, availability of these sources are limited in the market.

Generally, coconut husk contains a considerable level of potassium (Herath, 2014). However, it has been understood that direct application of king coconut husk introduces various practical difficulties such as slow decomposition of the immature shell and environmental problems due to water collection in the shells creating mosquito breeding grounds. Furthermore, the immature husk does not have higher moisture retention capacity compared to the mature coconut husk which makes a limitation of its use. Therefore, this study was conducted to investigate the possibility of developing an easy to use product from king coconut husks that can be used as a nutrient source for coconut cultivation and test its impact on major soil properties after application into bulk soil.

\section{MATERIALS AND METHODS Processing of King Coconut Husk}

King coconut husks $(\mathrm{KCH})$ discarded from nut water bottling factories were collected within one week of disposal. They were processed by burning in a kiln $(180 \mathrm{~cm} \times 120$ $\mathrm{cm} \times 150 \mathrm{~cm}$ ) lined with brick walls with an opening of $90 \mathrm{~cm}$ x $90 \mathrm{~cm}$ in a side wall. 


\section{Effect of King Coconut Husk as a Nutrient Source for Organic Coconut Cultivation}

Combustion of $\mathrm{KCH}$ was done under three categories: fresh (immediately after disposal); semi-dry (after two weeks of disposal) and dry (after four weeks of disposal). Initial fire was established inside the kiln using firewood and the kiln was heated until the temperature inside the kiln was approximately $600{ }^{\circ} \mathrm{C}$. The husks were loaded to the kiln approximately $500 \mathrm{~kg}$ at a time and they were allowed to burn partially for about one hour fueling the fire. Then, the kiln door was closed using a metal sheet. When the kiln was cooled, the product was taken out using a shovel. The product, nutrient supplementary material (NSM) was separately collected for analysis and six representative samples from each batch were analyzed.

The three types of NSM were separately analyzed for chemical properties including $\mathrm{pH}$, electrical conductivity, potassium content (Thomas, 1982), nitrogen (Bermmer and Malvaney, 1982), phosphorus and other micronutrients. Among the three categories of NSM preparation, the best condition was selected for field testing based on the properties of product, ease of handling the raw materials made from different husk conditions.

The field experiment was conducted to test the product in soil conditions of young coconut plantation (two-year-old) in the Intermediate Zone of Sri Lanka. The soil type was Madampe series (Orthidystric Regosols). The NSM from selected processing category
(T2) was tested against two other treatments (T1 \& T3) as follows.

- $\mathbf{T}_{1}$ : Conventional fertilizer application as per the recommendation of Coconut Research Institute of Sri Lanka (CRISL).

- $\mathbf{T}_{2}$ : K source supplied with NSM (based on the $\mathrm{K} \%$ of the product and CRISL recommended level), but rest of the nutrients were supplied as per the CRISL recommendation

- $\mathbf{T}_{3}$ : Conventional fertilizer application with Sulfate of Potash (SOP) as the potassium source

The quantities of fertilizer $(\mathrm{N}, \mathrm{P}, \mathrm{K}, \mathrm{Mg}$ ) and method of application was done according to the CRISL recommendation unless the changes are specifically mentioned (CRISL, 2012).

The experimental design was randomized completely block design (RCBD) with three replicates and six palms per plot. Before and after application of treatments, soil samples were collected from three representative locations of each plot at two different depths of $0-25 \mathrm{~cm}$ and $26-50 \mathrm{~cm}$. Samples were analyzed for soil $\mathrm{pH}$ (1: 2.5 soil: water), electrical conductivity, and exchangeable $\mathrm{K}$ (Thomas, 1982). Samples were collected representatively from each plot at three months after application of treatments.

The data were analyzed using SAS software to find out the effect of applying 
Herath, H.M.I.K. and Wijebandara, D.M.D.I.

NSM produced from king coconut husk on soil conditions and nutrient availability compared to the conventional fertilizer applied soils.

\section{RESULTS AND DISCUSSION}

Chemical properties of NSM from each batch of $\mathrm{KCH}$ are given in Table 1. $\mathrm{pH}$ values of NSM produced under all categories were above 10 . The availability of plant nutrients is greatly affected by soil $\mathrm{pH}$. Most of plant nutrients are available in neutral $\mathrm{pH}$ range of 6.5-7.5. Therefore, it is important to see the change of the $\mathrm{pH}$ of bulk soil as a result of application of NSM. According to the results, both soil $\mathrm{pH}$ and EC increased when processed material $(\mathrm{KCH})$ was in dry condition. However, leaving husk for drying became a problem in the rainy season. There were some practical difficulties of processing moist husks as they leave big unburnt particles that need burning at a second round.

Table 1. Chemical properties of processed king coconut husk of different categories

\begin{tabular}{lcc}
\hline Categories & pH & $\begin{array}{c}\text { EC } \\
(\mathbf{m S / c m})\end{array}$ \\
\hline $\begin{array}{l}\text { Batch 1 } \\
\text { (Moist) }\end{array}$ & $10.2 \pm 0.1$ & $48.3 \pm 6.2$ \\
$\begin{array}{l}\text { Batch 2 } \\
\text { (Semi dry) }\end{array}$ & $10.6 \pm 0.2$ & $58.6 \pm 3.5$ \\
$\begin{array}{l}\text { Batch 3 } \\
\text { (Dry) }\end{array}$ & $10.8 \pm 0.1$ & $65.8 \pm 2.1$ \\
\hline
\end{tabular}

The results show that NSM contains both macro and micro nutrients (Table 2). Especially, the potassium content of NSM is higher than that of most of organic manure and other locally available sources. Potassium content of most organic manure is in the range of $1-3 \%$ (Tennakoon and Bandara, 2003). It clearly shows the potential of NSM produced in any of the above conditions to be used if other factors are also favorable for application.

The presence of micro nutrients is also vital as they are essential nutrients to enhance coconut production. It is even more imperative for coconut cultivation in Sri Lanka as general fertilizer recommendation for coconut does not have a source of micro nutrients even though they are being continuously removed through the harvest and never returned or recycled back to the plantations. There is an increasing trend of nutrient availability with the dryness of the material used. In processing, there has been practical difficulties with moist husk. Therefore, semi-dry material is considered to be the most suitable in terms of easy handling and thus used for field testing in this study. Initial soil properties of the experimental site indicated that $\mathrm{pH}$ of the soil was slightly acidic and the nutrient levels including exchangeable $\mathrm{K}, \mathrm{Mg}$ and available $\mathrm{P}$ were very low (Table 3). However, this soil type has higher potential for coconut cultivation considering the physical properties including the depth and drainage (Somasiri et al., 2003).

\section{Soil pH}

As the governing factor of nutrient availability, changes in soil $\mathrm{pH}$ in response to treatment application was considered as a key 
factor in the determination of applicability. Even though there was an increase in soil $\mathrm{pH}$ (Table 3 and 4) in T2 (the NSM applied soil), the difference was not significant $(\mathrm{p}<0.05)$. This indicates that there is a potential to use NSM for young coconut irrespective of its high $\mathrm{pH}$. There were no significant difference between $\mathrm{pH}$ of top soil and sub soil in all the treatments (Table 4).

\section{Soil Electrical Conductivity}

Soil electrical conductivity (EC) is a measure of the amount of salts in soil (salinity of soil). It is well established that the excess salts hinder the plant growth by affecting the soilwater balance. There was a significant $(p<0.05)$ difference among the treatments when considering the soil EC of both top soil and sub soil, after treatment application (Table 5). The highest EC value was observed in the T2 (384.3 and $131.4 \mu \mathrm{S} / \mathrm{m}$ for top soil and sub soil, respectively). However, these EC values were within the tolerable level for coconut.

\section{Soil Potassium}

There was a significant $(\mathrm{p}<0.05)$ difference in soil exchangeable potassium level among the

Table 2. Nutrient availability of processed king coconut husk of different categories

\begin{tabular}{lccccccc}
\hline & N \% & K \% & Na \% & Ca \% & Mg \% & $\begin{array}{c}\text { Cu } \\
(\mathbf{p p m})\end{array}$ & $\begin{array}{c}\mathbf{Z n} \\
(\mathbf{p p m})\end{array}$ \\
\hline $\begin{array}{l}\text { Batch 1 } \\
\text { (Moist) }\end{array}$ & $2.1 \pm 0.1$ & $8.8 \pm 0.7$ & $1.6 \pm 0.1$ & $1.1 \pm 0.1$ & $0.9 \pm 0.3$ & $61.2 \pm 0.4$ & $1350 \pm 10$ \\
$\begin{array}{l}\text { Batch 2 } \\
\text { (Semi dry) }\end{array}$ & $2.4 \pm 0.2$ & $12.2 \pm 0.5$ & $2.8 \pm 0.3$ & $1.7 \pm 0.2$ & $1.1 \pm 0.2$ & $62.5 \pm 0.9$ & $1550 \pm 11$ \\
$\begin{array}{l}\text { Batch } \\
\text { (Dry) }\end{array}$ & $2.4 \pm 0.3$ & $13.2 \pm 0.4$ & $2.6 \pm 0.3$ & $1.8 \pm 0.3$ & $1.2 \pm 0.3$ & $62.5 \pm 0.7$ & $1522 \pm 12$ \\
\hline
\end{tabular}

Table 3. Initial chemical properties of soil used in the experimental location

\begin{tabular}{lc}
\hline \multicolumn{1}{c}{ Soil Properties } & Value $( \pm$ SD) \\
\hline Soil $\mathrm{pH}$ & $5.44 \pm 0.140$ \\
Soil EC $\left(\mathrm{mS} \mathrm{cm}^{-1}\right)$ & $19.93 \pm 0.410$ \\
Available Soil P $(\%)$ & $0.013 \pm 0.002$ \\
Exchangeable $\mathrm{K}(\%)$ & $0.006 \pm 0.001$ \\
Exchangeable $\mathrm{Ca}(\%)$ & $0.012 \pm 0.001$ \\
Exchangeable $\mathrm{Mg}(\%)$ & $0.002 \pm 0.001$ \\
\hline
\end{tabular}


soil exchangeable potassium level among the treatments in both top and sub soils. As given in Figure 1, T2 shows the highest amount of $\mathrm{K}$ in the top soil. There were no significant difference in potassium levels of the sub soil.
Potassium from inorganic fertilizers (MOP and SOP) releases faster and subjects to leaching from the soil which may be the cause for lower $\mathrm{K}$ levels in top soil of $\mathrm{T} 1$ and $\mathrm{T} 3$ (Figure 1).

Table 4. Soil $\mathrm{pH}$ three months after treatment application

\begin{tabular}{lcc}
\hline \multicolumn{1}{c}{ Treatment } & Top soil $^{*}$ & Sub soil $^{*}$ \\
\hline T1 & $5.77 \pm 0.75^{\mathrm{a}}$ & $5.30 \pm 0.48^{\mathrm{a}}$ \\
T2 & $6.25 \pm 0.23^{\mathrm{a}}$ & $5.46 \pm 0.19^{\mathrm{a}}$ \\
T3 & $5.69 \pm 0.12^{\mathrm{a}}$ & $5.55 \pm 0.11^{\mathrm{a}}$ \\
\hline
\end{tabular}

* Mean values indicated by the same letter along the columns are not significantly different at probability level of 0.05 .

Table 5. Soil EC levels after treatment application

\begin{tabular}{lcc}
\hline Treatment & $\begin{array}{c}\text { Top soil } \\
\left(\boldsymbol{\mu S} \mathbf{~ c m}^{-1}\right) *\end{array}$ & $\begin{array}{c}\text { Sub soil } \\
\left(\boldsymbol{\mu S} \mathbf{~ c m}^{-1}\right) \\
*\end{array}$ \\
\hline T1 & $181.5^{\mathrm{b}}$ & $113.0^{\mathrm{c}}$ \\
T2 & $384.3^{\mathrm{a}}$ & $131.4^{\mathrm{a}}$ \\
T3 & $141.4^{\mathrm{c}}$ & $119.8^{\mathrm{b}}$ \\
\hline
\end{tabular}

*Mean values indicated by the same letter along the columns are not significantly different at probability level of 0.05 .

Coconut being a high $\mathrm{K}$ demanding crop, it is imperative to have a steady supply of $\mathrm{K}$ throughout its growing period. As most of organic manure are low in potassium, there is a high potential for NSM to be used as a K source with organic manure.

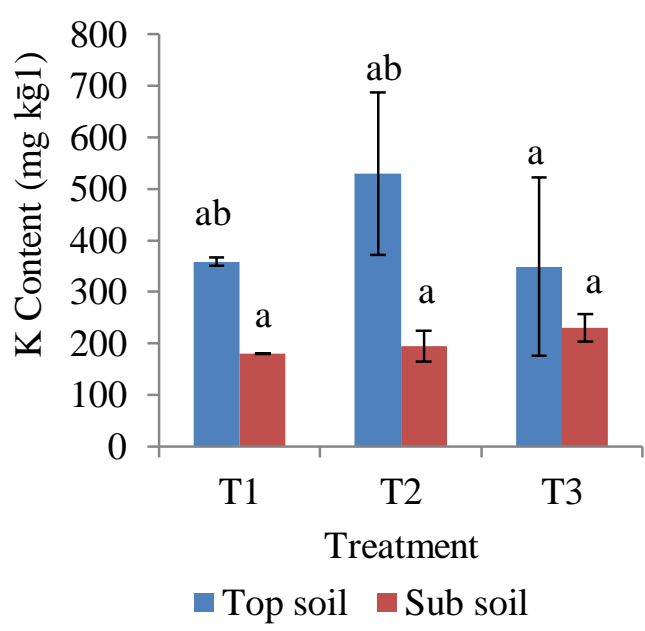

Figure 1. Soil K levels after incorporation of the treatments

\section{CONCLUSION}

King coconut husk $(\mathrm{KCH})$ which is a waste material from nut water exporting industry was used to develop a soil nutrient supplementary material to be used in coconut 
cultivation. Among the three categories of moist, semi-dry and dry coconut husk used for combustion, semi-dry $\mathrm{KCH}$ was found to be the best for processing in terms of time taken for processing and ease of handling. The product contained considerable amount of macro and micro nutrients. Even though the $\mathrm{pH}$ of the product (NSM) itself was higher, after application this into soil, there has not been a significant difference among treatments. The NSM made using $\mathrm{KCH}$ has higher level of $\mathrm{K}$ which makes it useful as a source of $\mathrm{K}$ to be used with organic manure for young coconut.

\section{REFERENCES}

Bermmer J.M. and Malvaney S. C. (1982). Nitrogen-Total. In: A. L. Page (Ed). Methods of Soil Analysis Part II. Chemical and Microbiological Methods. American Society of Agronomy. Wisconsin, USA.

Cooray, P.I., Weerassoriya, T. J. and Deturck, P. (1992). Effect of acidulated pigmatatic mica on growth and yield of rice and soil solution $\mathrm{K}, \mathrm{Mg}$, Ca. Journal of the Geological Society of Sri Lanka, 4: 69-75.

Coconut Research Institute of Sri Lanka (CRISL) (2012). Fertilizer Use and Land Suitability for Coconut Cultivation, Coconut Research Institute, Lunuwila, Sri Lanka.

Herath, H.M.I.K., Saumyakumara, A.P.A. and Tennakoon, N.A. (2007). Soil fertility status of common coconut growing soil series in Sri Lanka. Journal of the Soil Science Society of Sri Lanka, 18: 35-40.

Herath, H.M.I.K, Ranasinghe, K.L. and Tennakoon. N.A. (2008). Use of soil and foliar nutrient levels to identify the nutritional limitations of two coconut growing soils in Sri Lanka. In Proceedings of the Second Symposium on Plantation Crop Research, 16-17 October, 2008. BMICH, Colombo, Sri Lanka.

Herath, H.M.I.K. (2014). Potential of potassium supply in locally available soil amendments for use in coconut plantations. Journal of Food and Agriculture, 7(1-2): 18-24.

DOI: http://doi.org/10.4038/jfa.v7i12.5190

Somasiri, L.L.W., Nadarajah, N. and Amarasinghe, L. (2003). Soils of Coconut Triangle of Sri Lanka. Coconut Research Institute, Lunuwila, Sri Lanka. Tennakoon, N.A. and Bandara, S.D.H. (2003). Nutrient content of some locally available organic materials and their potential as alternative sources of nutrients for coconut. Cocos, 15: 23-30.

Thomas, G.W. (1982). Exchangeable Cations. In: Page A. L. (Ed). Methods of Soil Analysis Part II. Chemical and Microbiological Methods. American Society of Agronomy. Wisconsin, USA. 